

Digitized by the Internet Archive in 2011 with funding from University of Toronto 




\section{CONTRIBUTIONS OF THE}

\section{ROYAL ONTARIO MUSEUM OF ZOOLOGY}

No. 16. THE BIRDS OF THE VICINITY OF LAKE NIPISSING, ontario. By William E. Ricker and C. H. D. Clarke

Published under

THE REUBEN WELLS LEONARD BEQUEST 1939 



\title{
THE BIRDS OF THE VICINITY OF LAKE NIPISSING, ONTARIO
}

\author{
William E. Ricker and C. H. D. Clatake
}

\section{INTRODUCTION}

The observations from which this paper $^{1}$ is prepared were made intermittently over a number of years. The first writer lived at North Bay up to October, 1926, except for the months of July and August of each year, and made his first records of bird observations in 1922. From 1924 to 1926 spring migration records are fairly complete, as observations were made almost daily from early April to early June of those years. Autumn work was much less completely recorded, and absence of fall records does not necessarily imply absence of the species. Brief visits to North Bay in later years have supplied some additional information, and the months of June and July, 1929, were spent at Frank's Bay. All these observations have been carefully edited. Many observations were made with the assistance of Mr. Charles Ramsay, formerly of North Bay Normal School.

The second writer spent the months of June, 1932, and May and June, 1933, as well as a week in June, 1934, at Frank's Bay, while engaged in a study of the Ruffed Grouse, staying at the Ontario Fisheries Research Laboratory field station. Other students there have contributed observations, notably Dr. D. A. MacLulich whose records cover the four months April to July in 1934, and shorter periods in the two preceding years. The Division of Birds, Royal Ontario Museum of Zoology has furnished lists made by the Museum staff and others. Mr. J. L. Baillie, Jr. of the Museum staff has examined mounted specimens in the possession of Dr. F. W. McKee and Mr. E. Couchie of North Bay, which had been taken close to Lake Nipissing. These specimens, and those in the North Bay Normal School taken locally, are mentioned when specimens having more complete data are not available. Specimens in the Cleveland Museum of Natural History collected on the south shore of Lake Nipissing at Fish Bay in June, 1938, by Dr. J. W. Aldrich are noted when specimens were not repre-

${ }^{1}$ It is fitting that this publication appear as one of the Royal Ontario Museum of Zoology Contributions. Both of the authors were closely associated with the Museum while at the University of Toronto and the Museum's Division of Birds has played a part in the gathering of data for this paper and in seeing it through the press. Furthermore, the work fits into the general programme of the Museum in its effort to make as complete as possible accounts of local faunas hitherto inadequately reported on in the literature.

Curator, Division of Birds. 
sented in Ontario collections. Additional records are taken from published accounts, a list of which is appended.

\section{Physiography and Vegetation}

All of the observations and records included were made at points no more than ten miles distant from Lake Nipissing. This body of water lies at an elevation of 640 feet above sea-level, in the northern part of southern Ontario (see Snyder 1939), (Latitude $46^{\circ} \mathrm{N}$., Longitude $80^{\circ} \mathrm{W}$.). It is about 40 miles long and 20 miles wide, exclusive of three large bays: the West Arm, South Bay, and Callander Bay at the extreme eastern tip. Along the border of the lake, rocky headlands and stony stretches alternate with fine sand beaches, the latter being particularly well developed in the vicinity of the city of North Bay.

Practically all the land immediately about the lake has been logged off, the original forest having been dominated by red and white pine. To the north and east, some of it has been cleared for agriculture, but most of the old forest is now grown up with aspen, paper birch, large-toothed poplar and balsam fir. On the hills north of North Bay are considerable forests of yellow birch, sugar maple, basswood, red oak and Ostrya. In swampy places grow white elm, black ash, balsam-poplar, white cedar and alder, while true bogs have black spruce. Along the French River, the dry bluffs and islands bear rather stunted jack pines.

When cleared of its forest cover, the land surface appears much as the glaciers left it: rounded exposures of igneous rock forming hills of low elevation with numerous lakes set between them, these now in all stages of development into bogs and swamps. Such lakes are particularly common just east of North Bay, where twenty may be seen in an afternoon's walk. West of the city they are not so easily observed: much of the land close to Lake Nipissing was levelled somewhat when inundated by high water in early post-glacial times.

Bio-geographically, Lake Nipissing lies in the Great Lakes-St. Lawrence Region of the Forest Formation of Canada. Halliday (1937) places it in the Algonquin-Laurentides Section, in which in former times white pine probably reached its maximum development in Canada.

The majority of observations of birds were made at two points, North Bay and Frank's Bay, situated on the northeastern and southwestern shores of the lake respectively. The difference in latitude between the two is inconsiderable, but the climate of North Bay is probably somewhat cooler, because it gets the sweep of the prevailing westerly winds across the lake. Their effect would be most pronounced in spring, when the ice is commonly held at the eastern end of the lake for some time after the western end is clear. There are a few significant differences in the flora of the two 
places, e.g. Trillium grandiflorum is common along Bass Creek, Frank's Bay, but apparently absent from the neighbourhood of North Bay. As for birds, it is worthy of note that the time of arrival of April and May migrants was consistently earlier at Frank's Bay, although records at the two places in the same year are not available.

\section{List of Species}

The following list tabulates 209 species of birds, of which 136 are included on specimen evidence ( 66 of them in R.O.M.Z.). The number of species established as breeding in the area is 77. Species are classified as Abundant, Common or Frequent, Occasional and Rare. These terms have only relative significance, their application being affected by the size and secretiveness of the bird in question: a sparrow might be only "occasional" when the same numbers of loons would be an "abundance." Dates immediately following species names are of first records in years when continuous observations were being made over the likely period of arrival. Those for 1924, 1925 and 1926 refer to arrivals at North Bay (W. E. Ricker), for 1932 and 1933 arrivals at Frank's Bay (C. H. D. Clarke), for 1934 arrivals at Frank's Bay (D. A. MacLulich). Records up to and including 1929 are from the first writer, as are all observations at North Bay unless otherwise stated. Records at Frank's Bay from 1932 onward are from the second writer, except as indicated.

The names and the arrangement used are after Taverner (1934). The following abbreviations are used:

R.O.M.Z. - Collection of the Royal Ontario Museum of Zoology

C.M.N.H.-Collection of Cleveland Museum of Natural History

N. S. Coll.-Mounted birds in the North Bay Normal School

McKee Coll.-Mounted birds belonging to Dr. F. W. McKee.

Gavia immer. Common Loon.-Apr. 30/34. Observed rarely at North Bay and commonly at Frank's Bay, throughout the summer. Specimen in the N. S. and McKee Coll, and an adult male referred to the Lesser Loon, Gavia immer elasson, taken with 3 others in fish-nets near North Bay on June 8, 1906, is in the collection of Mr. J. H. Fleming. Recorded as common on Lake Nipissing by Hamilton (1893).

Gavia stellata. Red-THroated Loon.-Observed Sept. 18/24; one reported shot in West Arm, autumn, 1925. Specimen in N. S. Coll.

Colymbus grisegena. RED-NECKED GREBE.-A specimen taken locally is in the N. S. Coll, and Bent (1919) gives May 10 as an occurrence date for Lake Nipissing.

Colymbus auritus. Horned GREBE.-Three records: Sept. 29 and 
()ct. 10/25, (the latter in N.S. Coll.) and a set of four eggs, said to be of this species, in R.O.M.Z. collected July 1, 1915 on Lake Nipissing by IV. P. Young and recorded by Baillie and Harrington (1936).

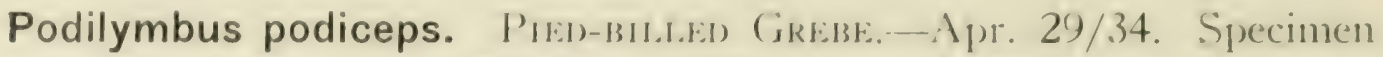
taken in North Pay, Apr. 24/23, and Thompson (1922) records it as a common stmmer resident at the west end of Lake Nipissing in 1904, two specimens having been secured on Aug. 29. Frank's Bay: June 25/32, female and 9 young seen; June $7 / 33$, female and newly-hatched brood seen (nest collected on June 10 and in R.O.M.Z.) ; June 29/34, well-grown young in R.O.M.Z., by D. A. MacLulich. A young bird from Frank's Bay taken on July 7, 1930 by W. R. Dymond is in R.O.M.Z.

Pelecanus erythrorhynchos. White Pelican.-Fleming (1900) records a male shot on May 27, 1899 in the western arm of Lake Nipissing. It was shot by an Indian boy and was mounted by Mr. Oliver Spanner for Mr. G. W. McFarland, of Cache Bay.

Ardea herodias. Great Blue Heron.-Apr. 13/34. Frequent, except immediately about North Bay. Specimens in N. S. and McKee Coll. Heronry of 3 to 6 nests observed on a small island of the Goose group, 1930 and later; discovered by the Fisheries Laboratory staff. Recorded as common in 1904 by Thompson (1922).

Casmerodius albus. AMERICAN EGRET.-Seton (1885) records a specimen from Lake Nipissing, shot in 1883. This specimen is still preserved in Toronto, at the Old Mill on the Humber.

Botaurus lentiginosus. American Bittern.-Apr. 24/24, May 4/25, May 5/26; May 1/34. Summer resident, found frequently in suitable cover, such as the marsh north of Callander Bay, or that on the old Callander road.

Ixobrychus exilis. Least Bittern.-One brought in to North Bay, June 4/26 (N. S. Coll.). o collected in marsh at West Bay, June 11/34 (in R.O.M.Z.), and a set of three eggs near the elbow of West Bay, June 22/34 (in R.O.M.Z.), both by D. Chitty. One seen at Fish Bay in June, 1938, by Dr. J. W. Aldrich.

Branta canadensis. CANAdA Goose.-Small flocks settled on Marten Lake, just east of North Bay, May 5 and 12/26. Flock of 60 at Frank's Bay, May $9 / 34$ by D. A. MacLulich.

Anas platyrhynchos. MaLlard Duck.-Fenale taken in West Arm, fall of 1925. One specimen in McKee Coll., o in N. S. Coll. 
Anas rubripes. Black Duck.-Apr. 18/24, Apr. 13/25, May 5/26; Apr. 22/34. Frequently seen on the small lakes and ponds, as well as Lake Nipissing. Apparently breeding on the Goose Islands. At Frank's Bay a nest of 10 eggs was found, June 9/33, in a Chamaedaphne bog more than a quarter-mile from water, and at a fair elevation. The female never came to the nest again; nest and eggs were taken to the laboratory, where on June 16 two of the eggs hatched in an incubator. The nest and five eggs and the two young are in R.O.M.Z. Given as breeding at South Bay by "Nipissing" (1891).

Mareca americana. Baldpate.-Lake Nipissing specimen in McKee Coll.

Dafila acuta. Pintail.-North Bay: pair, June 7/26. Frank's Bay: May 2/34 (D. A. MacLulich). Recorded by Bell (1861) as having been shot at Lake Nipissing by Alexander Murray and by "Nipissing" (1891) as breeding at South Bay. The breeding requires confirmation. Specimens in N. S. and McKee Coll.

Nettion carolinense. Green-winged Teal.-Male taken in West Arm, fall of 1925. Frank's Bay, May 2/34 (D. A. MacLulich). Specimens in N. S. and McKee Coll. and recorded by Bell (1861) as having been shot on Lake Nipissing by Alexander Murray. Stated by "Nipissing" (1891) to breed at South Bay, but this requires confirmation.

Querquedula discors. Blue-Winged Teal.-Male taken in West Arm, fall of 1925, in N. S. Coll. Two pairs at North Bay, Apr. 18/36. Two seen in mid-June, 1938 at Fish Bay by Dr. J. W. Aldrich of the Cleveland Museum of Natural History. Specimens were collected at Lake Nipissing by Alexander Murray according to Bell (1861) and it breeds at South Bay according to "Nipissing" (1891).

Aix sponsa. Wood Duck.-Few summer residents at Frank's Bay. Male in R.O.M.Z. was taken there on May 16, 1934, by Albert St. Denis. Breeds at South Bay according to "Nipissing" (1891).

Nyroca americana. RedHeAd,-Male from West Arm, fall of 1925, in N. S. Coll.

Nyroca collaris. Ring-NECKed Duck.--Two pairs on a boggy lake near North Bay, May $8 / 25$; discovered by C. Ramsay. Sometimes shot in autumn (N. S. Coll.).

Nyroca valisneria. CANVAS-BACK.-A specimen taken locally is in the N. S. Coll. 
Nyroca marila. (iREATER SCALP DeCK and Nyroca affinis. L LESER Scaup Dick. - Scaup were occasionally seen alout North liay in early May. A number shot in the West Arm, 1925, included both species. At Frank's Bay both were considered present in spring, and the Lesser Scaup was present in the latter part of May. A Lake Nipissing specimen of marila is in the McKee collection.

Glaucionetta clangula. Common Golden-eye-April 16/24, May $9 / 25$, Apr. 30/26; Apr. 12/34. Frequently observed in spring, occasionally in fall. Breeds on the Twin lakes east of North Bay. At Frank's Bay, a dead duckling of this species, with egg-tooth still attached, was found on June $18 / 33$ at the base of a 25 -foot cliff. It was quite decomposed. Apparently the path from the nest tree to water lay over this cliff, and one youngster was killed in the tumble. (Adult o in R.O.M.Z. taken by A. M. Fallis and J. R. Dymond at Frank's Bay on Aug. 17, 1933.)

Charitonetta albeola. Buffle-IieAd.-Frank's Bay, Apr. 17/34 (D. A. MacLulich). Shot in the West Arm, autumn of 1924 and 1925. Specimens in N.S. and McKee Coll.

Clangula hiemalis. Old-Sguaw.-A specimen taken locally is in the N. S. Coll.

Melanitta deglandi. White-Winged Scoter.-A specimen taken locally is in the N. S. Coll.

Melanitta perspicillata. Surf Scoter.-A specimen taken locally is in the N. S. Coll.

Lophodytes cucullatus. Hooded Merganser.-Several specimens shot in West Arm, fall of 1924 and 1925, and there are specimens in the N. S. and McKee Coll. At Frank's Bay, observed on Bass Creek throughout the summer. A $\sigma^{7}$ in R.O.M.Z. was secured at West Arm on Sept. 28, 1935, and received from the Ontario Department of Game and Fisheries.

Mergus merganser. Common Merganser.-Drake seen near North Bay, April 28 and May 16/24. Breeds fairly commonly about Lake Nipissing. Downy young collected by F. P. Ide, June 10/29, Sandy Island and by A. L. Tester, July 12/30, Goose Island, are in R.O.M.Z. Nests with 7 and 8 eggs at Goose Islands, June 30/29; one clutch had hatched by July 22, the other by July 24. Two adults taken Nov. 6-9, 1933 at Lake Nipissing and received from S. C. Downing are in R.O.M.Z., as are also five adults from West Arm taken Oct. 26, 1935, received from Ontario Department of Game and Fisheries. 
Mergus serrator. Red-Breasted Merganser.-Occasional on Lake Nipissing in spring and fall migration. (N. S. Coll.). Young mergansers from the lake have proved to be the preceding species; the specimen recorded by Thompson is not extant, and he now suggests it be disregarded.

Astur atricapillus. American GoSHAWK.-Individuals seen near North Bay, Nov. 10/24 and Sept. 7/25.

Accipiter velox. Sharp-Shinned Hawk.-Apr. 24/24, May 21/25, Apr. 22/26. Observed occasionally, until late September. At Frank's Bay it is present in summer, in small numbers.

Buteo borealis. RED-TAILED HAWK,-Observed rarely, as summer resident, Apr. 21 to Sept. 7. (N. S. Coll.).

Buteo lineatus. Red-shouldered Hawk.-In summer of 1933 an individual of this species soared overhead on each of several trips up the Shoal Lake road from Frank's Bay.

Buteo platypterus. Broad-winged Hawk.-Apr. 12/24, Apr. 25/ 25, May 8/26. A pair appeared to nest in the hardwoods just north of North Bay. The commonest summer hawk in wooded areas, though hardly "frequent" in its occurrence. (o'R.O.M.Z., Frank's Bay, Aug. 31, 1931, F. E. J. Fry and J. R. Dymond.)

Buteo lagopus. Common Rough-LegGed Hawk.-A specimen taken locally is in the N. S. Coll.

Aquila chrysaetos. Golden Eagle.-A specimen was taken alive at Powassan on Mar. 5/30 by Mr. H. J. Bochne, and sent to the Toronto Zoo, where it died on May 5. It is now in the R.O.M.Z.

Haliaetus leucocephalus. BALd EAGLE.-Regular summer resident at Frank's Bay; seen as early as Apr. 29/34 (F. E. J. Fry). A specimen taken locally is in the collection of Mr. E. Couchie. Prof. A. F. Coventry saw a nest with one young at Frank's Bay on July 10, 1930. Recorded from Big Chaudière Falls, French River, by Hoover (1902).

Circus hudsonius. Marsh Hawk.-Apr. 24/24, Apr. 4/25, Apr. 17/26; Apr. 13/34. Occasional but regular summer resident, seen up to the end of September. (N. S. Coll.). Recorded by Thompson (1922) as common in 1904.

Pandion haliaetus. Osprey.-Apr. 21/34. Frequently seen in the Frank's Bay region; a nest located June $21 / 29$ was demolished in the winter of 1930. Rarely seen at the eastern end of the lake. Thompson (1922) records a specimen taken Aug. 30/04 at the west end of Lake Nipissing. 
Falco peregrinus. DUCK HAwk.-One, May 17/24.

Falco columbarius. PlGion Hawk.-May 2/24, Apr. 22/25, Ajr. $18 / 26 ;$ Apr. 1.3/34. In spring migration usually seen hy the lake shere. Pair taken by Mr. D. Chitty in the Wrest Pay, June 24/34 (o R.(J.M.Z.) and another pair seen at the Goose Islands, June 27/34. The behaviour of the birds in both cases suggested nesting, so the species is probably a rare breeding bird. One was observed at Fish Bay by Dr. Aldrich in mid-June, 1938.

Falco sparverius. American Sparrow Hawk.-May 3/24, May 6/25, Apr. 17/26; Apr. 6/34. Frequent, the most common hawk in clearings. Seen in fall up to Sept. 13. One (R.O.M.Z.) Frank's Bay, Sept $5 / 31$, F. Firy.

Canachites canadensis. SPRUCE Grouse.-Found wherever there are spruce swamps, in which it nests. Female and young, French river, July 12/29. Frank's Bay: female and 3 young, July $15 / 31$; nest and 6 eggs June 1/32.(D. A. MacLulich), hatched June 16. Recorded as common at North Bay in Aug. 1896 by Miller (1897) and listed for Lake Nipissing by Jervis (1906). (May and October females, nest, eggs and young in R.O.M.Z.).

Bonasa umbellus. Ruffed Grouse.-Seen throughout the year. This species (and the preceding) is subject to a cycle of abundance which was studied by the second writer (Clarke, 1936). It was noted as definitely scarcer in 1926 than in 1925. In 1932 and 1933 it became quite abundant, but in 1934 very few young survived the summer at Frank's Bay. Frank's Bay: nest and 10 eggs, June 1/32: first young noted June 8/32 and June 6/33. Miller (1897) records it as common during Aug. 1896 at North Bay, and Jervis (1906) records its occurrence at Lake Nipissing. (Adults, nest, eggs and young in R.O.M.Z.).

Lagopus lagopus. WiLlow PTARMIGAN.-Fleming (1901) records that two were shot at Callander in Dec. 1896. Mr. Fleming informs us that two others, which he examined, were shot at Cache Bay during the same winter, one of which (No. 21865) is in his collection.

Pedioecetes phasianellus. 'Sharp-tailed Grouse.-North Bay was, except for scattered records, the southern limit of the great migration of these birds in the fall of 1932. Some were reported during the next summer, these being probably the survivors of this flight. (Snyder 1935).

Phasianus colchicus. Common Pheasant.-Reported seen regularly just south of North Bay in 1935. One reported killed at Frank's Bay, winter 1934-35 (D. A. MacLulich). 
Porzana carolina. SorA.-Pair seen at North Bay, June 4/24. Frank's Bay: June 8/32 and June 15/34 (D. A. MacLulich).

Gallinula chloropus. Common Gallinule.-One taken about 1921 at the mouth of the Sturgeon River on Lake Nipissing by Dr. F. W. McKee, is in R.O.M.Z. (Baillie and Harrington, 1936).

Fulica americana. American Coot.-One taken in West Arm, Sept. 1925. Specimens in N. S. and McKee Coll. One seen at Fish Bay in mid-June, 1938, by Dr. J. W. Aldrich and recorded by Bell (1861) as having been shot at Lake Nipissing by Alexander Murray.

Charadrius semipalmatus. Semipalmated Plover.-Frequent on Nipissing beaches during the first half of September, occasional during the latter half of May. J. L. Baillie saw 4 on the beach at Callander, Aug. $14 / 34$.

Oxyechus vociferus. Killdeer Plover.-Apr. 5/24, Apr. 6/25, Apr. 20/26. Summer resident, frequently seen on cultivated land, and in autumn along the beaches. (N. S. Coll.). Recorded as rare in 1903 and 1904 by Thompson (1922).

Squatarola squatarola. Black-Bellied Plover.-Sept. 6/24, Sept. 10/25, Sept. 3/26. Occasional but regular autumn migrant on Nipissing beaches, staying till late October. Male, in R.O.M.Z., was taken at the village of Nipissing Oct. 16/33, by B. Willings.

Arenaria interpres. Common Turnstone.-One, Sept. 11/24, Nipissing beach.

Philohela minor. American Woodcock.-Observed May 18/24, June 21/25, near North Bay where signs of its presence are not uncommon. Nest and 4 eggs, North Bay, June 8/26, discovered by C. Ramsay.

Capella delicata. Wilson's Snipe--May 6/24, Apr. 24/25, May $5 / 26$. Frequent in marshy spots, sometimes congregating in flocks of 20 or more in the fall. Stays to mid-October. One in R.O.M.Z. was taken by Mr. Leadley on October 15, 1898, at Sturgeon Falls.

Phaeopus hudsonicus. Hudsonian Curlew.-One taken locally by Dr. McKee, now in R.O.M.Z.

Actitis macularia. Spotted Sandpiper.-May 7/24, May 19/25, May 6/26; Apr. 30/34. Migrant and resident, frequently seen, up to late September. Frank's Bay: 3 newly-hatched young, June 19/33. Recorded as common in 1904 by Thompson (1922). 
Tringa solitaria. Soltary SANDPper.-May 19/24, May 24/25, May 16/26, May 20/29. Occasionally but regularly seen about small lakes and streams in late May and early September.

Totanus melanoleucus. GREATER ÝLLOW-LECS- I single specinen by a small pond, May 10/26, discovered by C. Ramsay. The calls of Yellow-legs are freeuently heard overhearl on rainy nights in May, September and October. (N. S. Coll。).

Calidris canutus. KNot.-One taken May 28/32, at Frank's Bay (R.O.M.Z.).

Pisobia melanotos. Pectoral Sandpiper.-One on Nipissing beach fall of 1922. Flocks of 3-6 observed Oct. $17 / 25$ to Oct. $27 / 25$ by a small stream just west of the North Bay dock. They bored into the mud in the manner of a Woodcock. One taken at Sturgeon Falls on Oct. 15/98 by Mr. Leadley is in R.O.M.Z.

Pisobia fuscicollis. White-RUMPed SANDPIPER.-Two in fall of 1922 along Nipissing beach. One, May 27/25, Chippewa Creek, North Bay.

Pisobia bairdi. BAIRD's SANDPIPER.-Thompson (1922) records a specimen, Sept. 7/04, taken from a flock.

Pisobia minutilla. Least Sandpiper.-Occasional in September, rare in May, along Nipissing beaches.

Pelidna alpina. Dunlin.-Two seen Sept. 18/29, Nipissing beach. Two taken May 28/32, Frank's Bay, are in R.O.M.Z.

Ereunetes pusillus. Semipalmated Sandpiper.-Frequent during the first half of September, occasional in late May, along Nipissing beaches. One taken at Frank's Bay, May 28/32 (R.O.M.Z.).

Limosa haemastica. Hudsonian Godwit.-Specimen taken at Cache Bay by Dr. McKee "some years ago" (R.O.M.Z.).

Crocethia alba. Sanderling.-Sept. 2/24, Sept. 10/25, Sept. 3/26. Frequent throughout September, and in 1924 to Oct. 8. The most common of the beach birds in fall, at times seen in flocks of 15 or 20 .

Stercorarius sp. JAEGER.-A jaeger, probably parasiticus, was observed for two weeks in September and October, 1923.

Larus hyperboreus. Glaucous Gull.-One, Oct. 2-4/24. 
Larus argentatus. Herring Gull.-Apr. 5/24, Apr. 3/25, Apr. 14/26. Abundant summer resident, staying to mid-November at least. Nests on various islands of the Manitou, Goose and French River groups. Eggs were found from June 10 to 30 , and young from June 10 to July 11, 1929. Specimen, C.M.N.H.

Larus delawarensis. RING-BILLED GULL.-Immature birds observed in the fall of 1923 and Sept. 24/25. Thompson (1922) records it as a tolerably common summer resident in 1904 .

Larus philadelphia. Bonaparte's Gull.-May 21/24, May 19/25, May 25/26; May 24/34. Each spring a flock of 20-50 remained near the North Bay dock for about a week. Immature birds occasionally seen in autumn. Specimen, McKee Coll.

Sterna hirundo. Common Tern.-May 26/24, May 28/25, May 28/26; May 18/33, May 24/34. Frequent on Lake Nipissing, staying to mid-September. Nesting colony of $100-200$ on a small isolated island of the Goose group in 1929. Eggs in mostly incomplete sets were seen June 30 , eggs and newly-hatched young July 11, young of various ages July 22-24. On July 28 another colony was observed about a small island just cast of the entrance to South Bay. Flocks, and later mated pairs, stayed about Frank's Bay until June 13/32 and June 14/33; after this they left for the breeding grounds and were seldom seen. Specimen, McKee Coll.

Hydroprogne caspia. CASPIAN TERN.-Two individuals observed in September, 1923.

Chlidonias nigra. Black Tern.-North Bay: one, May 27/24; three, June 6/25. Manitou Islands: June 14/32 (J. G. Oughton).

Zenaidura macroura. Mourning Dove.-Two at North Bay, apparently migrating westward, Apr. 28/24. Frank's Bay: May 23/34 (D. MacLulich). Near Sturgeon Falls, Aug. 26/35.

Ectopistes migratorius. PAssenger Pigeon.-Occurred in the Nipissing area, (Mitchell, 1935, p. 581).

Coccyzus erythropthalmus. Black-Billed Cuckoo.-May 25/33, May 30/34. Seen occasionally at North Bay, more commonly at Frank's Bay, where one was carrying food to young, June 26/33. o Frank's Bay, R.O.M.Z., June 4/33.

Otus asio. Screech Owl.-One was noted in mid-June, 1938, by Dr. J. W. Aldrich of the Cleveland Museum of Natural History who made a brief visit to Fish Bay and there is a specimen taken locally in the Normal School Collection. 
Bubo virginianus. GREAT HorNED ()WL.- ()casionally heard. Wellgrown young found near North liay. June 11/24. Adult taken Feb. 24/26 (N. S. Coll.). Three young from Callander are in R.O.M.Z.

Nyctea nyctea. SNowY OWL.-A specimen taken locally is in the N. S. Coll.

Surnia ulula. HAwk OWL.-Specimens taken near North Bay, Oct. 29/24, Nov. 18/24, Oct. 5/25 (N. S. Coll.).

Strix varia. BARRED OWL.-Taken near North Bay, Jan. 7/23 (N. S. Coll.). Seen at close range in North Bay city, Apr. 1/24.

Scotiaptex nebulosa. Great Grey OwL.-Specimen taken near North Bay, fall of 1927 ( N. S. Coll.). Taverner (1912) records the taking of two juveniles in Chisholm Township, just east of Lake Nipissing, by Mayor Kelly of Powassan, July 31/11. Fisher (1893) records the stomach contents of one shot at Lake Nipissing on Oct. 29, 1889, containing four meadow mice and one shrew and the R.O.M.Z. files contain a record of one seen at Little Sturgeon River near North Bay on Apr. 20/35 by Mrs. Edgar Hobbs.

Asio wilsonianus. Long-EARED Owl.-An individual of this species, shot on Lot No. 17, Section 14, Corbeil, on Oct. 9, 1934, by E. Laurin, had been banded by Frederick N. Gallup on Apr. 22, 1934, at Escondido, California. The bird carried U.S. Biological Survey Band No. 661987. Full documentary reports on the banding and return of this bird are on file at the R.O.M.Z. and constitute one of the most amazing cases of migration in the history of North American ornithology (Lincoln, 1936). One taken locally, in the McKee Coll.

Cryptoglaux funerea. Little Boreal Owl.-One, taken locally, is in N. S. Collection.

Cryptoglaux acadica. AcAdian Owl.-Specimen brought in, Apr. $17 / 26$ ( N. S. Coll.).

Antrostomus vociferus. Whip-POOR-WILl.-May 13/24, May 18/25; May 9/33, May 3/34. Summer resident, exceptionally common at Frank's Bay, apparently less so at North Bay.

Chordeiles minor. Nightнawk.-June 1/24, May 28/25, May 28/ 26; May 19/33, May 19/34. Common on both sides of the lake. At Frank's Bay they were seen catching cockroaches (Parcoblatta pennsylvanica) on the bare rocks. French River: 2 eggs, June 14/21. North Bay: 2 eggs on Normal School roof, June 27/25. Frank's Bay: 2 eggs, June 21/32 (J. G. Oughton) ; 2 eggs, June 10/33. 
Chaetura pelagica. Chinner Swift.-May 11/24, May 14/25, May 15/26; May 6/33. Frequent. Each spring a vortex of several hundred would circle over the main street of North Bay, concentrated about the chimneys of the old Royal Theatre. Young seen in ventilators of North Bay Collegiate Institute, June, 1926. Common at Frank's Bay in chimneys of the laboratory building. Green (1930) states that a Chimney Swift captured by C. J. Pifher at Trout Lake, near North bay had been banded on Oct. 16/28 at Chattanooga, Tennessee.

Archilochus colubris. Ruby-throAted HummingBiRd.-May 20/ 24, May 20/25, May 18/26; May 16/33, May 17/34. Latest fall record on Sept. 13. Frequent summer resident: deserted nest found at North Bay. Recorded from Lake Nipissing by Jervis (1906).

Megaceryle alcyon. Belted Kingfisher.-Apr. 19/24, Apr. 23/25, May 5/26; Apr. 19/34. Nest-hole seen May 29/23. (McKee Coll.). Common in 1904 according to Thompson (1922).

Colaptes auratus. Flicker.-Apr. 19/24, Apr. 22/25, Apr. 9/26; Apr. 18/34. Abundant. Nest and 6 eggs June 3/24; nest and eggs, also nest and young, June 16/24; young, July 2/25; young, June 20/26. Specimen, N. S. Coll.

Ceophloeus pileatus. Prleated WoOdPecker.-Regular permanent resident, but not as common as the smaller woodpeckers. A nest was found by C. Ramsay near North Bay. (McKee and N. S. Coll.).

Melanerpes erythrocephalus. RED-HEADED WoOdPECKER.-We were greatly surprised to find that Thompson (1922) lists this bird as frequent near North Bay in 1904. Although one report of its occurrence in the town in recent years has come to us, neither of the present writers has seen it north of Washago, where the Precambrian Shield begins. There is some evidence suggesting that its numbers in Ontario have diminished, which is interesting in the light of this restriction of its range.

Sphyrapicus varius. Yellow-Bellied Sapsucker.-Apr. 23/24, Apr. 23/25, Apr. 18/26; Apr. 13/34. Common. Nest at Frank's Bay, June 1/32 (D. MacLulich). Specimen, R.O.M.Z., Frank's Bay, May $26 / 33$.

Dryobates villosus. HAIRY WOODPECKER.-Common, occurs throughout the year. One from Frank's Bay, July 2/34 and one from Nipissing, Oct. 16/33 are in R.O.M.Z. 
Dryobates pubescens. IDOWNY WOOIPECKER-Common, occurs throughout the year. Nest, June 16/24. (q R.O.M.Z., Frank's Bay, May $12 / 3.3)$.

Picoides arcticus. ARCTIC 'THREE-TOEN MOOHPEKER-Fight records near North Bay, September to December. Recorded by Miller (1897) as common at North Bay in Aug., 1896.

Tyrannus tyrannus. EAstern Kixgind.-May 18/24, May 23/25, May 16/26; May 14/33, May 17/34. Common. Frank's Bay, nest and two eggs, June 27/33 and nest (in R.O.M.Z.), July 20/30. Specimen, C.M.N.H.

Myiarchus crinitus. Cresten Flycatcher.-Occasional but regular summer resident at Frank's Bay and French River; not seen at North Bay.

Sayornis phoebe. Eastern Phoebe-Apr. 28/24, Apr. 7/25, Apr. 22/26; Apr. 13/34. Common in suitable places. Frank's Bay: nest and 5 eggs, May 25/33.

Empidonax flaviventris. Yellow-Bellied Flycatcher.-North Bay, May 31/25; Frank's Bay, June 9/32. Probably breeds in alder swamps. Recorded by Miller (1897) as common at North Bay in Aug., 1896.

Empidonax trailli. Traill's Flycatcher..-May 21/25, May 23/ 26; May 14/33. Common. North Bay: nest with 4 eggs, June 21-July 2/25. ल (R.O.M.Z.), North Bay, May 24/03, S. L. Thompson.

Empidonax minimus. Least Flycatcher.-May 22/24, May 17/ 25, May 18/26; May 14/33, May 18/24, May 20/29. Abundant. Observed building nest, June 14/33, at Frank's Bay. o7 (R.O.M.Z.), Frank's Bay, May 30/33.

Myiochanes virens. Eastern Wood Pewee.-June 5/24, May 31/ 26; May 22/33, May 28/34. Fall record, Sept. 16/27. Common at Frank's Bay, less so at North Bay, and scarce there in 1925. $0^{7}$ (R.O.M.Z.), Frank's Bay, June 9/33. Baillie and Harrington (1937) record a nest found at North Bay on June 10/04 by S. L. Thompson.

Nuttallornis mesoleucus. Olive-sided Flycatcher.-May 25/33, May 18/34. Common summer resident, except close to North Bay. \& (R.O.M.Z.), Frank's Bay, May 29/33.

Otocoris alpestris. Horned LARK.-Mar. 22/24, Mar. 8/25, Mar. 19/26. Arrives while the ground is still snow-covered. Common migrant and summer resident. 
Iridoprocne bicolor. Tree Swallow.-May 3/24, Apr. 23/25, Apr. 22/26; Apr. 18/34. Abundant. Nest and 6 eggs, June 20/26. \& (R.O. M.Z.), Frank's Bay, May 29/32.

Riparia riparia. Bank Swallow.-June 11/24, May 21/25. Local breeding resident, whose numbers are restricted by the frequency of nesting sites.

Hirundo erythrogaster. Barn Swallow.-May 13/24, May 4/25, May 12/26. Common. Several nests in an old barn at Frank's Bay.

Petrochelidon albifrons. Cliff Swallow.-Fairly common at Callander, July 2/35, and nests observed (R.O.M.Z. field party of 1935).

Progne subis. Purple Martin.-In the spring of 1920 or 1921 a large flock, perhaps 50, rested under the eaves of the North Bay post-office for a few days. They did not remain, however, and were not seen in later years, although reports of more recent occurrence have been received.

Perisoreus canadensis. Canada JAY.-Occasional near North Bay. Common permanent resident in wilder situations. Young seen at Frank's Bay, June 3/32. Recorded by Miller (1897) as common at North Bay during Aug., 1896.

Cyanocitta cristata. BluE JAY.-Common at Frank's Bay, fewer at North Bay. Summer resident. (N. S. and McKee Coll.).

Corvus corax. RAVEN.-Recorded in numbers at North Bay by Thompson (1891) on Jan: 18/87.

Corvus brachyrhynchos. American Crow.-Mar. 22/24, Mar. 9/ 25, Mar. 18/26. Much in evidence at North Bay from the time of its arrival. Pair with fledged young, June 16/25. Large migrating flocks, Oct. 7 and 10/24. Recorded by Eifrig (1909) as present at North Bay in late Mar., 1908. At Frank's Bay seldom seen except flying over, and breeding only on some islands of the French River. (N. S. Coll.).

Penthestes atricapillus. Black-CAPped Chickadee.-Common all year. Feeding young at Frank's Bay, June 20/33. Specimens, C.M.N.H.

Penthestes hudsonicus. Brown-headed Chickadee.-Oct. 16/24, one in a flock of the preceding. May breed in some of the more extensive spruce bogs.

Sitta carolinensis. White-breasted Nuthatch.--Single individuals, Apr. 2 and Oct. 31/25. Lockwood (1935) records three, Dec. 23/34. 
Sitta canadensis. Reidbrastin Nuthatcil-May 18/24, May $8 / 25$, May 20/29. May winter in small numbers, but chiefly migratory. A common summer resident, but remarkably scarce in 1926. Specimen, C.M.N.H.

Certhia familiaris. LRow C CRERER.-Apr. 19/24, Apr. 25/25, Apr. 18/26; Apr. 19/34. Common migrant, and regular summer resident, but not found during winter.

Troglodytes aedon. House Mrex.-May 11/24, May 28/25, May $15 / 26$, May 20/29. Fairly common in suitable clearings; recorded up to Sept. 26/25. Nesting June 4/25; nest and 5 eggs, June 20/26. Specimens, C.M.N.H.

Nannus hiemalis. Winter Wren.-Apr. 24/24, Apr. 24/25, Apr. 28/26; Apr. 18/34. Fairly common, summer resident; records to Oct. 9/25. Seen feeding young at Frank's Bay, June 19/33. Recorded by Miller (1897) as common at North Bay during Aug., 1896.

Telmatodytes palustris. Long-billed Marsh Wren.-June 8/24 and May 4/25, in the Typha marsh along the old Callander road.

Cistothorus stellaris. Short-billed Marsh Wren.-Small colony in a swale of sedges near North Bay, June 14 and $17 / 25$; but not in 1924 or 1926. Heard south of North Bay, May 25/32 (Clarke). Present at. Frank's Bay in 1932, but not in 1933.

Dumetella carolinensis. Catbird.-May 14/24, May 20/25, May 23/26; May 19/33, May 17/34. Frequent. Seen building nest at Frank's Bay, June $1 / 32$.

Toxostoma rufum. Brown Thrasher.-May 6/24, May 2/25, May 20/26; May $5 / 34$. Frequent at Frank's Bay, especially in brûlé; less common at North Bay. Two adults with young at Frank's Bay, July 23/34 (D. MacLulich). (N. S. Coll.).

Turdus migratorius. American Robin.-Apr. 8/24, Mar. 26/25, Apr. 20/26; Apr. 9/34. Abundant. Migrating flocks seen up to mid-May, and in autumn to Oct. $27 / 24$ and Oct. $31 / 25$. First nests June $1 / 24$, May $14 / 25$, May $18 / 26$, May $20 / 29$, June $7 / 32$, June $2 / 33$. One female characterized by three white tail feathers (as was at least one of her brood) nested successfully on the ground. Two specimens, Frank's Bay, (R.O.M.Z.).

Hylocichla mustelina. Wood Thrush.-Occasional but regular summer resident in mature deciduous forest. 
Hylocichla guttata. Hermit Thrush.-Apr. 23/24, Apr. 28/25, May 4/26; Apr. 21/34. Abundant. Frank's Bay: nest and 4 eggs (in R.O.M.Z.), May 31/33. Recorded during the fall of 1903 by Thompson (1922). Two adults (R.O.M.Z.).

Hylocichla ustulata. Olive-Backed Thrush.-May 26/24, May 19/25. May 23/26; May 29/33. Frequent in spring and fall migration, and summer resident in coniferous areas. Two adults, Frank's Bay, (R.O.M.Z.).

Hylocichla fuscescens. Wilson's Thrush.-May 18/25, May 20/ 26; May 20/29, May 14/33, May 15/34. Frequent, Frank's Bay: nest with 2 young, June $22 / 29 ; 2$ nests with 4 eggs each, June 8/32. Two adults, Frank's Bay, (R.O.M.Z.).

Sialia sialis. Red-BReasted Bluebird.-Apr. 4/25; Apr. 9/34. Occasional and rather local. Pair building nest June 16/25. Seen to Oct. $18 / 24$.

Regulus satrapa. Golden-Crowned Kinglet.-Apr. 19/24, Apr. $25 / 25$, Apr. 22/26; Apr. $18 / 34$. Frequent in migration, particularly in 1924; also a summer resident. Recorded by Miller (1897) as common at North Bay during Aug. 1896 and by Thompson (1922) as abundant during Sept. and Oct. 1903.

Corthylio calendula Ruby-crowned Kinglet.-Apr. 24/24, Apr. $25 / 25$, May 4/26; Apr. 21/34. Common summer resident in evergreen woods. Noted during Sept. and Oct. 1903 by Thompson (1922).

Anthus spinoletta. American Pipit.-May 14/25, May 15/26; May $25 / 33$. Regularly seen near the lakeshore each autumn; abundant in spring and fall of 1925 .

Bombycilla garrula. Bohemian Waxwing.-Seen during winter of 1921-22 (E. M. Ricker). Specimen in N. S. Coll.

Bombycilla cedrorum. Cedar Waxwing.--June 7/24, May 29/25, June 2/26; May 23/33, May 29/34. Frequent, in autumn to Sept. 18/24. Nest with 3 young found at Frank's Bay, Aug. 29/35 by D. A. MacLulich (specimens in R.O.M.Z.).

Lanius borealis. Northern Shrike.-Oct. 8 and Dec. 29/25; Apr. 21/26, in song. (N. S. Coll.).

Lanius ludovicianus. Common Shrike.-Spring of 1922; Apr. 21/ 26. Rare. R.O.M.Z. field party of 1935 noted three at Rutherglen, July 2 and secured one juvenile. 
Sturnus vulgaris. Com MoN STARI.1.-Apr. 18/34. Baillie (1928) gives the first North Bay record as the spring of 1927 when seven pairs were found nesting by C. Ramsay. From 1928 onward, a regular summer resident. Lockwood (1935) has a winter record of 8, seen Dec. 23/34, lut it appears to be chicfly migratory. First seen at Frank's liay in 1932 , when it was alrearly nesting on May 25. On May 19/33 the first brood for that year hatched. The cornices of the laboratory building were occupied each year by nesting starlings. Bigamy was proven when it was seen that three birds were responsible for two broods simultaneously. (N. S. and McKee Coll.).

Vireo flavifrons. Yellow-throated Vireo.-One, June 3/24.

Vireo solitarius. Blue-headed Vireo.-May 26/24; May 15/33, May 3/34. Quite common. In fall to Sept. 17/24 and Sept. 26/25. Pair feeding a fledgling, Aug. 23/25. o Frank's Bay, May 15/33 (R.O.MI.Z.).

Vireo olivaceus. Red-eyed Vireo.-June 5/24, May 29/35, May 25/26; May 19/33, May 18/34. Abundant. Nest and 4 eggs at Frank's Bay, June 14/33. A young Cowbird was taken from a nest which also contained 2 young vireos, at Frank's Bay on July 7, 1930, by J. R. Dymond. Nest and adults (R.O.M.Z.).

Vireo philadelphicus. Philadelphia Vireo.-May 25/33. Taken June 9 and 15/32 at Frank's Bay, and observed throughout June. Not common, but a regular summer resident. Three adults (R.O.M.Z.).

Vireo gilvus. Warbling Vireo.-June 11/24, May 29/25, June 10 / 26. Occasional, at North Bay.

Mniotilta varia. Black And White Warbler.-May 14/24, May 16/25, May 20/26, May 20/29; May 14/33, May 18/34. Abundant. Fall, Sept. 19/29. Seen feeding young at Frank's Bay, June 24/33. Specimens, C.M.N.H.

Vermivora peregrina. Tennessee WARbler.-May 26/24, May 20/ 25, May 23/26. Occasional migrant.

Vermivora celata. Orange-Crowned Warbler.-Two, May 18/26.

Vermivora ruficapilla. Nashville WArbler.-May 16/24, May 4/ 25, May 18/26; May 15/33, May 4/34. Fall, Sept. 8/27, Sept. 19/29. Abundant. Seen feeding young at Frank's Bay, June 25/33. Two adults (R.O.M.Z.).

Compsothlypis americana. PARUla MARbler.-May 26/24, May 17/25, May 26/26; May 19/33, May 21/34. Fall, Oct. 6/24, Sept. 
$25 / 25$. Frequent migrant, and probably breeds in small numbers. of May 19/33, Frank's Bay (R.O.M.Z.).

Dendroica aestiva. Yellow Warbler.-May 18/24, May 20/25, May 25/26; May 14/33, May 11/34. Fall, Aug. 25/25, Sept. 1/24. Abundant. Breeds commonly, even throughout the city of North Bay. Frank's Bay: nest with 3 eggs, June $12 / 29$; nest and 1 egg, May 30/33, clutch completed (4 eggs) June 2. Nest taken at Frank's Bay is in R.O. M.Z. (young left June 28). Specimens, C.M.N.H.

Dendroica magnolia. Magnolia Warbler.-May 16/24, May $17 /$ 25, May 20/26; May 16/33, May 18/34. Fall, Sept. 8/27, Sept. 19/29. Frequent. Nest and 5 eggs at Frank's Bay, June 9/33 (D. MacLulich).

Dendroica tigrina. CAPe May Warbler.-May 20/24, May 11/25, May 18/26; May 20/29, May 18/34. Fall, Sept. 14/25. Frequent migrant in May. Thompson (1922) records a specimen.

Dendroica caerulescens. Black-throated Blue Warbler.-May 25/24, May 19/25, May 27/26, May 20/29; May 19/33, May 18/34. Common migrant, and summer resident. of Frank's Bay, May 19/33 (R.O.M.Z.).

Dendroica coronata. Myrtle Warbler.-May 12/24, Apr. 30/25, May 7/26; May 3/34. Fall, up to Oct. 1/24 and Oct. 10/25. Abundant migrant. Feeding young at Frank's Bay, June 25/33. ơ Frank's Bay, June 25/32 (R.O.M.Z.).

Dendroica virens. Black-throated Green Warbler.-May $17 /$ 24, May 18/25, May 23/26; May 13/33, May 18/34. Fall, Sept. 2/24, Sept. 7/26. Common migrant, and summer resident.

Dendroica fusca. Blackburnian Warbler.-May 25/24, May $17 /$ 25, May 22/26, May 18/29; May 19/33, May 18/34. Frequent migrant, and summer resident. (N. S. Coll.).

Dendroica pensylvanica. Chestnut-sided Warbler.-May 25/24, May 17/25, May 31/26; May 15/33, May 19/34. Abundant. Nest and 4 eggs at Frank's Bay (in R.O.M.Z.), June 6/33 (D. MacLulich). Two specimens (R.O.M.Z.).

Dendroica castanea. Bay-breasted Warbler.-May 25/24, May 23/25; May 19/34. Occasional and irregular migrant, but on May 25/24 listed as the "most abundant warbler" of a "wave" comprising many species. 


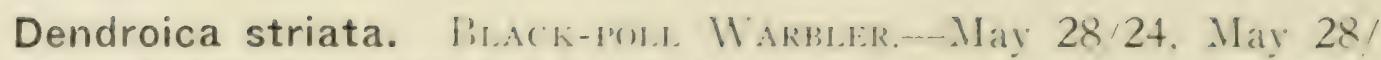
25: May 31/32, May 23/33, May 21/34. Occasional migrant, late May and early June. ơ Frank's Bay, May 27/33 (R.O.M.Z.).

Dendroica pinus. Pine Warbler,-May 14/33. Fairly common along the French River, lut not seen at North Bay. Seen carrying food to young, June 26/33, at Frank's Bay. ( $0^{7}$ Frank's Bay, May 14/33, R.O. II.Z.).

Dendroica discolor. Pratrie Warbler. One seen June 24/33 at Frank's Bay by the second writer, who is familiar with the species along the Lake Huron shore, where it is regular. Seen at 10 feet with field glasses.

Dendroica palmarum. Palm Warbler.-May 17/24, May 17/25, May 18/26, May 20/29; May 14/33, May 6/34. Fall, Sept. 13/24, Oct. $3 / 25$, Sept. 9/28. Frequent in migration. ㅇ Frank's Bay, May 19/33, (R.O.M.Z.).

Seiurus aurocapillus. Oven-Bird-May 26/24, May 20/25, May 23/26, May 20/29; May 14/33, May 18/34. Abundant. Frank's Bay: nest with 2 young and 1 egg just hatching (R.O.M.Z.), June 16/32; nest with 5 eggs, June 15/32 (D. MacLulich). Specimen C.M.N.H.

Seiurus noveboracensis. Northerx IVater-Tifresh.--May 16/25, May 23/26. Occasional in migration, and local summer resident.

Oporornis philadelphia. Mourning Warbler.-May 24/33. North Bay: seen in June, 1923. Frank's Bay: feeding young June 25/33; also June 23/34 (D. MacLulich). Localized in brushy patches. Recorded by Miller (1897) as common at North Bay in Aug., 1896.

Geothlypis trichas. Maryland Yellow-throat.-May 22/24, May 20/25, May 20/26; May 19/33, May 19/34. Fall, Sept. 13/24, Sept. $5 / 25$. Abundant summer resident. (N. S. Coll.). Dr. J. W. Aldrich found a nest in mid-June, 1938, at Fish Bay.

Wilsonia pusilla. Black-capped Warbler.-June 6/24, May 23/25, May 23/26; May 18/33, May 21/34. Fairly common migrant.

Wilsonia canadensis. Canada Warbler.-June 5/24, May 29/25, May 27/26; May 19/33, May 21/34. Common. Recorded by Miller (1897) as common at North Bay during Aug., 1896. Feeding young at Frank's Bay, July 2/34 (D. MacLulich). (Young, Frank's Bay, July 3/34, R.O.M.Z.). 
Setophaga ruticilla. American Redstart.-May 18/24, May 20/25, May 23/26, May 20/29; May 16/33, May 21/34. Abundant. Nest and 4 eggs at Frank's Bay, June 15/32 (D. MacLulich). (Two adults, R.O.M.Z.).

Passer domesticus. English Sparrow.-Abundant permanent resident in North Bay. Thompson (1888) states that two were seen at North Bay in the winter of $1885-6$ by John Bourk. More were seen in 1886 and in Jan., 1887, a flock of 100 was seen around yards feeding on manure piles and hayseeds. Dr. Aldrich found a pair and nest at Fish Bay in June, 1938.

Dolichonyx oryzivorus. Bobolin K.-Frank's Bay: May 19/33 (E. S. Pentland) ; a female taken June 17/33 (D. MacLulich) in R.O.M.Z. A few observed at Nosbonsing, East Ferris, by R.O.M.Z. party of 1935, on July 2. Two seen between North Bay and Sturgeon Falls, Aug. 18-19, 1931, by T. F. McIlwraith and recorded from North Bay in 1934 by Dr. Prior (Baird, 1935).

Sturnella magna. Eastern Meadowlark.-Apr. 21/24, Mar. 27/ 25, Apr. 22/26; Apr. 28/34. Abundant; cited as rare in 1904 by Thompson (1922). Young just able to fly, June 16/25, Aug. 30/26. ( $q$ Frank's Bay, May 28/32, R.O.M.Z.).

Agelaius phoeniceus. Red-winged Blackbird.-Apr. 25/24, May 2/25, May 5/26; Apr. 7/34. Abundant. Latest record Oct. 9/24. Nest and 3 eggs (in R.O.M.Z.) at Frank's Bay, May 28/33. (Specimens, R.O.M.Z.).

Icterus galbula. Baltimore Oriole.-Occasional. Nests observed four miles west of North Bay, one report of the bird in town. Frank's Bay: June 2/32, June 3-22/33, May 20/34 (D. MacLulich). West Arm: June 23/34 (D. Chitty). (2 adults, R.O.M.Z.).

Euphagus carolinus. Rusty BlackBIRD.-Apr. 21/24, Apr. 13/25, Apr. 20/26. Latest record Sept. 16/27. Frequent throughout April and most of May: occasionally heard singing. Not yet observed in summer, but 2 seen Aug. 18-19, 1931, between North Bay and Sturgeon Falls by T. F. McIlwraith.

Quiscalus quiscula. Crow BlackBird.-Apr. 18/24, Apr. 3/25, Apr. 22/26; Apr. 10/34. Fall, to Sept. 12/26. Abundant. North Bay: fledglings in nest, June 14 and 21/25, July 8/29; nests with eggs May 30 and June 20/25, June 10 and 20/26, June 30/29. Frank's Bay: Nest (in R.O. M.Z.) and 4 eggs, June $11 / 33$; the nest was much like that of a Red-wing, in low bushes 3 feet above water. A pair nested in 1929 on Tern rock. Two adults (R.O.M.Z.). 
Molothrus ater. Cowbird.-Apr. 24/25, Apr. 21/26. Frequent in cleared sections. Fledgling with Robin as foster-parent, June 15/25. Young in R.O.M.Z. taken at Frank's Bay on July 7/30 was taken from the nest of the Red-eyed Vireo.

Piranga erythromelas. SCARLLT TANAGLR.-May 30/25, May $22 /$ 26; May 19/33, May 19/34. Common. Seen feeding young, June 27/33, at Frank's Bay. Nest and one egg found at Frank's Bay, Aug. 29/30, by F. E. J. Fry, J. G. Oughton and A. M. Fallis, are in R.O.M.Z. (Adult, R.O.M.Z.).

Richmondena cardinalis. Cardinal.-Female taken at Hardy Bay on the French River by Dr. F. W. McKee, in the autumn about 1930, now in N. S. Coll. (Baillie and Harrington, 1937).

Hedymeles ludovicianus. Rose-breasted Grosbeak.-May 26/24, June 3/25, May 25/26; May 18/33. Especially common along small streams, rare or absent from pure coniferous bush. Nesting pair at Frank's Bay, June 29/34 (D. MacLulich). Specimen, C.M.N.H.

Passerina cyanea. Indigo Bunting.-Taken June 10/04 at North Bay by Thompson (1922). Seen June 15/32 at Frank's Bay. One seen Aug. 18-19/31 between North Bay and Sturgeon Falls by T. F. McIlwraith. On May 30/38 J. L. Baillie saw single males at North Bay and Beaucage.

Hesperiphona vespertina. Evening Grosbeak.-Groups of up to 40 fed on seeds of Acer negundo in North Bay each winter except 1922-23, their absence that year being associated with a failure in the supply of keys. Their arrival varies from mid-December to early March, and they leave in early or mid-April. Large flocks were observed out of town as late as May 7/26, and single specimens on May 18 and 25/25. Found breeding in Algonquin Park in 1934, by the second writer, their breeding in the Nipissing region is considered quite likely. (McKee and N. S. Coll.).

Carpodacus purpureus. Common Purple Finch.-May 5/24, May 9/25, May 4/26; May 2/34. Common summer resident, breeds. Fall to Sept. 26/25. Adults and young (R.O.M.Z.).

Pinicola enucleator. Pine Grosbeak.--Regular winter visitor, but not often seen in town. Flocks observed as early as Oct. 11/24, and as late as Mar. 30/26. Not infrequently heard in song in early spring. Apparently also a rare summer resident, as a singing male was found at Frank's Bay, July 2/34 (D. MacLulich). One in R.O.M.Z. was secured at French River, Parry Sound District, on Nov. 6/13 by J. E. Keays and another in R.O.M.Z. was taken at Nipissing, Nov, 6-9/33. 
Acanthis linaria. Red-Polled Linnet.-Records from early November to late May, abundant in late March and early April. Eight large dark individuals seen in a flock of the common sort, Apr. 18/23, were probably A.l. rostrata.

Spinus pinus. Pine Siskin.-Occasional in winter, becoming frequent toward the end of March; records from early October to early May. Recorded by Miller (1897) as common at North Bay during Aug., 1896. Probably breeds in the vicinity, as a few may be seen in North Bay city each June, feeding on heads of dandelion (Taraxacum). \% Frank's Bay, May 9/33 (R.O.M.Z.).

Spinus tristis. American Goldfinch.-May 28/24, May 14/25, May 28/26; May 19/33, May 19/34. Common summer resident. Feeding young Sept. 24/25.

Loxia curvirostra. Red Crossbill.-Small flock on red pines, Mar. $17 / 23$; reported common throughout that winter. Johnson (1929) records a specimen from North Bay taken Sept. 7 (1896) by G. S. Miller.

Loxia leucoptera. White-Winged Crossbill.-A few with the preceding, Mar. 17/23.

Pipilo erythrophthalmus. EAstern TowheE.-May 3/25, May 15/ 26, May 20/29; May 3/34. Fall, Sept. 26/25. Rare summer resident, the above being the only observations.

Passerculus sandwichensis. Savannah Sparrow.-Apr. 24/24, Apr. 22/25, Apr. 30/26; Apr. 19/34. Latest record Sept. 26/25. Very common summer resident on cleared land about North Bay. \& Frank's Bay, May 13/33 (R.O.M.Z.).

Pooecetes gramineus. Vesper Sparrow.-Apr. 21/24, Apr. 22/25, Apr. 21/26. Latest record Sept. 26/25. Abundant summer resident about North Bay.

Junco hyemalis. Slate-Colored Junco.-Apr. 7/24, Apr. 2/25, Apr. 20/26; Apr. 10/34. In fall migration, early September to late October. Common summer resident, and very abundant in migration, but no winter records. Recorded by Miller (1897) as common during Aug., 1896, at North Bay. Frank's Bay: nest and 4 eggs, June $1 / 32$; nest in R.O.M.Z. (Adult, R.O.M.Z.).

Spizella arborea. Tree Sparrow.-Apr. 11/24, Apr. 7/25, Apr. 27/26; Apr. 23/34. Very abundant in spring migration, which lasts to mid-May. Fall records up to late October. One observed in spring at North Bay had tail feathers all white. 
Spizella passerina. (IIIPINi SPARRow-Apr. 25/24, Apr. 30/25, May 13/26; Apr. 18/34. Frepuent about clearings and in North Bay. Nest and cegers. June 16/24; young out of nest June 29/25 and June 29/26. Frank's Bay: nest and 4 eggs, June 2/33, J. M. B. Corkill, in R.().M.Z. (Specimens, C.M.N.H.).

Zonotrichia leucophrys. WIITE-CROWnEI SPARRow.-May 15/24, May 5/25, May 8/26; May 6/34. Frequent in spring migration, which lasts to the last week in May. Fall, Sept. 30/24, Oct. 3/25.

Zonotrichia albicollis. White-throated SPArrow.-May 2/24, Apr. 22/25, Apr. 27/26; May 2/34. Abundant. Recorded by Miller (1897) as common during Aug., 1896, at North Bay. Latest fall record, Oct. 10/25. Frank's Bay: nest and 4 eggs, June $7 / 32$; nest and 5 eggs, June 4/33 (E. S. Pentland). (Three adults and nest, R.O.M.Z.).

Passerella iliaca. Fox Sparrow.-Apr. 19/24, Apr. 13/25, Apr. 28/26. Frequent at North Bay during spring migration, which, however, lasts only about 10 days. Fall record, Oct. 21/25. (Specimen, N. S. Coll.).

Melospiza georgiana. Swamp Sparrow.-May 14/24, May 2/25, May 16/26; May 4/34. Fall, Sept. 18 and Oct. 6/24. Abundant. Frank's Bay: nest and 4 eggs, June 22/34. (Young, R.O.M.Z.).

Melospiza melodia. Song Sparrow.-Apr. 8/24, Mar. 26/25, Apr. 19/26; Apr. 10/34. In fall, up to mid-October, and a stray as late as Nov. 18/24. Abundant. Nests with eggs: June 1, 3 and 11/24; May 28 and June 12/25; with young: June 7 and 11/24, June 21 and July $2 / 25$. Frank's Bay: nest and 5 eggs, June 18/32; nest and 5 eggs, June $7 / 34$ (D. MacLulich). ('Two adults, R.O.M.Z.).

Calcarius lapponicus. Lapland Longspur.-Three males, May 6/ 26, at North Bay. At Frank's Bay, two full-plumaged males were discovered May $16 / 33$ by E. S. Pentland, and one collected by the second writer. (Specimen, R.O.M.Z.).

Plectrophenax nivalis. Snow Bunting.-Records from late October to early May: frequently seen in spring and fall, occasional in winter. Recorded by Thompson (1922) as very common in late fall of 1903. (Specimen, N. S. Coll.).

\section{LITERATURE}

Baillie, JAs. L., Jr., 1928. Further notes on the starling in Ontario. Can. FieldNat., $42: 177$.

Baillie, Jas. L., Jr., and Paul Harrington, D.D.S., 1936-7. The distribution of breeding birds in Ontario. Trans. Roy. Can. Inst., $21: 1-50,199-283$. 
Baird, Robert L., 1935. The season. Bird-Lore, $37: 469$.

Bell, Robert, 1861. Catalogue of birds collected and observed around Lake Superior and Huron in 1860. Can. Nat. and Geol., 6:275.

Bent. Arthur Cleveland, 1919. Life histories of North American diving birds. U.S. Nat. Mus., Bull., $107: 20$.

Clarke, C. H. D., 1936. Fluctuations in numbers of Ruffed Grouse, Bonasa umbellus Linné, with special reference to Ontario. Univ. Toronto Stud., Biol. Ser., 41.

EIfrIG, G., 1909. Winter birds of new Ontario and other notes on northern birds. Auk, $26: 56$.

Fisher, A. K., 1893. The hawks and owls of the United States in their relation to Agriculture. U.S. Dept. Agric. Div. Orn. \& Mamm., Bull., 3:157-8.

Fleming, James H., 1900. Ontario bird notes. Auk, 17:177

Fleming, James H., 1901. A list of the birds of the districts of Parry Sound and Muskoka, Ontario. Auk, 18:37.

Green. Wyman R., 1930. The banding of Chimney Swifts at Chattanooga, Tennessee. Bird-Banding, 1:112.

Halliday, W. E. D., 1937. A forest classification for Canada. Dept. Mines and Resources, Forest Service Bull. 89, Ottawa.

Hamilton, James Cleland, 1893. The Georgian Bay, an account of its position, inhabitants, mineral interests, fish, timber and other resources. P. 120.

Hoover, M. H., 1902. In the wilds of northern Canada. Rod and Gun in Can., $3: 4-6$.

Jervis, H., 1906. Backwoods' reminiscences. Rod and Gun and Motor Sports in Can., 8:374.

Johnson, Charles W., 1929. Some notes on certain of the Hippoboscid flies. Bull. N. E. Bird-Banding Assoc., 5:49-50.

Lincoln, Frederick C., 1936. Recoveries of banded birds of prey. Bird-Banding, $7: 45$.

Lockwood, Robert D., 1935. Christmas bird census, 1934, at North Bay. Can. Field-Nat., $49: 44$.

Miller, Gerrit S., Jr., 1897. Notes on the mammals of Ontario. Proc. Boston Soc. Nat. Hist., $28: 1-44$.

Mitchell, M. H., 1935. The passenger pigeon in Ontario. Roy. Ont. Mus. Zool., Contrib. No. 7.

"Nipissing", 1891. Wild rice. Forest \& Stream, $37: 310$.

Seton, Ernest E. T., 1885. Interesting records from Toronto, Canada. Auk, 2:336.

Snyder, L. L., 1935. A study of the sharp-tailed grouse. Univ. Tor. Stud., Biol. Ser., 40.

SNyder, L. L., 1939. A plan of Ontario subdivisions and their names for naturalists. Can. Field-Nat., $53: 22-24$.

Taverner, P. A., 1912. Two interesting records for Canada. Auk, 29:397.

Taverner, P. A., 1934. Birds of Canada. Nat. Mus. Canada, Bull. 72.

Thompson, Ernest E., 1888. Notes on the English sparrow. Forest \& Stream, $30: 204-5$.

Thompson, Ernest E., 1891. The birds of Manitoba. Proc. U.S. Nat. Mus., $13: 568$.

Thompson, Stuart L., 1922. The birds of North Bay, Ontario and vicinity in 1904. Can. Field-Nat., $36: 161-168$. 





\section{O N T R I B U T I O N S \\ OF THE}

\section{ROYAL ONTARIO MUSEUM OF ZOOLOGY}

This series contains reports of Museum studies, including faunal surveys. Except where otherwise stated the price is twenty-five cents a copy.

1. Faunal Survey of the Lake Nipigon Region, Ontario, by J. R. Dymond, L. L. Snyder and E. B. S. Logier. 58 pages.

2. A Faunal Survey of the Lake Abitibi Region, Ontario, by the staff of the Royal Ontario Museum of Zoology. 46 pages.

3. A Faunal Investigation of King Township, York County, Ontario, by L. L. Snyder and E. B. S. Logier. 42 pages (out of print).

4. A Faunal Investigation of Long Point and Vicinity, Norfolk County, Ontario, by L. L. Snyder and E. B. S. Logier. 120 pages (out of print).

5. Some Account of the Amphibians and Reptiles of British Columbia, by E. B. S. Logier. 26 pages (out of print).

6. A Study of the Sharp-tailed Grouse, by L. L. Snyder. 66 pages.

7. The Passenger Pigeon in Ontario, by Margaret $\mathrm{H}$. Mitchell. Records of the history of the now extinct wild pigeon (Ectopistes migratorius) in Ontario. Paper, \$1.00. Cloth, \$1.50. 181 pages.

8. The Distribution of Breeding Birds in Ontario, by James L. Baillie, Jr., and Paul Harrington. 134 pages.

9. Some Freshwater Fishes of British Columbia, by J. R. Dymond. 14 pages.

10. The Birds of the Lake St. Martin Region, Manitoba, by T. M. Shortt and Sam Waller. 51 pages.

11. Baird's Sparrow, by B. W. Cartwright, T. M. Shortt and R. D. Harris. 44 pages.

12. Ontario and its Avifauna, by L. L. Snyder, and The Museum's Bird Collection, by J. L. Baillie. 14 pages.

13. Birds of Algonquin Provincial Park, Ontario, by D. A. MacLulich. 47 pages.

14. A Faunal Investigation of Western Rainy River District, Ontario, by L. L. Snyder. 57 pages.

15. The Fishes of the Ottawa Region, by J. R. Dymond. 43 pages.

16. The Birds of the Vicinity of Lake Nipissing, Ontario, by William E. Ricker and C. H. D. Clarke. 25 pages. 




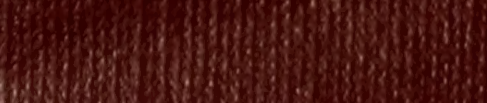

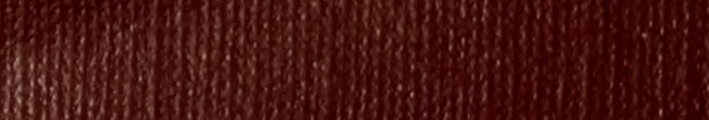

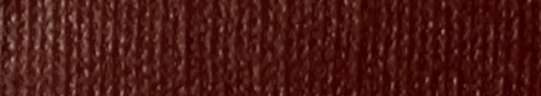
Q30) 